\title{
Effect of branched-chain amino acid supplementation on insulin resistance and quality of life in chronic hepatitis $\mathrm{C}$ patients
}

\author{
ALICIA OCAÑA-MONDRAGÓN ${ }^{1}$, JOSÉ ANTONIO MATA-MARÍN ${ }^{2}$, MARIO URIARTE-LÓPEZ ${ }^{3}$, \\ CAROLINA BEKKER-MÉNDEZ ${ }^{1}$, ENRIQUE ALCALÁ-MARTÍNEZ ${ }^{2}$, ROSA MARÍA RIBAS-APARICIO ${ }^{4}$, \\ LUIS ANTONIO URIBE-NOGUÉZ ${ }^{1,4}$, DULCE MARÍA RODRÍGUEZ-GALINDO ${ }^{5}$ and \\ MARÍA DE LA LUZ MARTÍNEZ-RODRÍGUEZ ${ }^{1}$
}

\author{
${ }^{1}$ Unidad de Investigación Biomédica en Infectología e Inmunología; ${ }^{2}$ Unidad Médica de Alta Especialidad, Hospital de \\ Infectología, Centro Médico Nacional La Raza, Instituto Mexicano del Seguro Social, Mexico City 02990; \\ ${ }^{3}$ Departamento de Investigación y Desarrollo, AYDSA Aminas y Derivados S.A. de C.V., Mexico City 06400; \\ ${ }^{4}$ Departamento de Microbiología, Programa en Biomedicina y Biotecnología Molecular, Escuela Nacional \\ de Ciencias Biológicas, Instituto Politécnico Nacional, Mexico City 11340; ${ }^{5}$ Departamento de \\ Psicología Clínica, Unidad Médica de Alta Especialidad, Hospital de Especialidades, Centro Médico \\ Nacional La Raza, Instituto Mexicano del Seguro Social, Mexico City 02990, Mexico
}

Received September 3, 2017; Accepted October 19, 2017

DOI: 10.3892/br.2017.1012

\begin{abstract}
The incidence rate of insulin resistance (IR) in patients with chronic hepatitis $\mathrm{C}(\mathrm{CHC})$ is high. Recently, branched-chain amino acids (BCAA) have been shown to attenuate IR in CHC patients; however, their effect on patient quality of life remains unclear. Therefore, the aim of the current prospective study was to determine the effects of BCAA supplement on IR and health-related quality of life (HR-QoL) in patients with CHC. In the study, 20 non-diabetic patients with $\mathrm{CHC}$, who were non-responders to peginterferon- $\alpha$ and ribavirin, were recruited. Patients took a BCAA supplement once a day ( $30 \mathrm{~g}$, after a minimum 10-h overnight fast) for 3 months. Serum levels of glucose, insulin, albumin, triglycerides and cholesterol were measured at 0 and 3 months. Additionally, IR was measured using the Homeostasis Model Assessment-IR, HR-QoL was assessed using the 36-item Short Form Health Survey and viral load was measured by reverse transcription polymerase chain reaction using Taqman probes. The Wilcoxon signed-rank test was used to determine statistical significance. The results indicated that $70 \%$ of the subjects were positive for IR, which decreased to $50 \%$ by the end of the study; furthermore, $85 \%$ of the subjects
\end{abstract}

Correspondence to: Dr Alicia Ocaña-Mondragón, Unidad de Investigación Biomédica en Infectología e Inmunología, Hospital de Infectología, Centro Médico Nacional La Raza, Instituto Mexicano del Seguro Social, Avenida Jacarandas Esquina Vallejo S/N, Colonia La Raza, Delegación Azcapotzalco, Mexico City 02990, Mexico

E-mail: oama14@yahoo.com.mx

Key words: insulin resistance, branched-chain amino acids, chronic hepatitis $\mathrm{C}$, health-related quality of life, hepatitis $\mathrm{C}$ virus demonstrated some level of improvement. Overall, the BCAA treatment significantly decreased IR $(\mathrm{P}=0.006)$ and augmented serum albumin concentration $(\mathrm{P}=0.008)$ compared with basal values. Additionally, by the end of the treatment, viral load and triglycerides levels had decreased, though these results were not significant $(\mathrm{P}=0.084$ and $\mathrm{P}=0.080$, respectively). BCAA treatment also improved $\mathrm{HR}-\mathrm{QoL}$ regarding role limitations due to physical health problems $(\mathrm{P}=0.017)$, role limitations due to emotional problems $(\mathrm{P}=0.026)$ and social function $(\mathrm{P}=0.008)$. In conclusion, BCAA supplementation reduced IR and improved HR-QoL in patients with CHC. These findings support the application of IR therapy as a possible therapeutic strategy for hepatitis $\mathrm{C}$ infection.

\section{Introduction}

Infection with hepatitis $\mathrm{C}$ virus (HCV) is a health problem worldwide. At present, an estimated 170 million people are infected, and between 2-3 million new cases are diagnosed each year, most of which will result in chronic infection (1). $\mathrm{HCV}$ belongs to the Flaviviridae family and is an enveloped virus with a $9.6 \mathrm{~kb}$ positive-sense, single-stranded RNA genome (2). The virus encodes three structural proteins (core, E1 and E2) and six nonstructural proteins (NS1, NS2, NS3, NS4B, NS5A and NS5B) (3). Six genotypes of HCV have been identified, with GTIa and GTIb, and to a lesser extent, GT2 and GT3a, being the predominant genotypes observed in Mexicans (4). HCV causes metabolic alterations that have been associated with lipogenesis, hepatic steatosis, insulin resistance (IR), metabolic syndrome and diabetes (5).

The replication cycle of HCV has predominantly been associated with alterations in lipid metabolism (6); however, a number of studies have indicated that a direct activity of the virus's core protein may alter glucose metabolism, eventually causing IR (7-10). A proposed mechanism is that the HCV 
GT1 core protein blocks the insulin signaling cascade protein kinase $\mathrm{B}(\mathrm{Akt}) / \mathrm{mammalian}$ target of rapamycin (mTOR)/ribosomal protein S6 kinase $\beta-1$ by increasing the expression of tumor necrosis factor $\alpha(\mathrm{TNF}-\alpha)$ and suppressor of cytokine signaling $3(11,12)$. This may lead to inactivation of insulin receptor substrate 1 and block glucose entry into cells by preventing the activation of glucose transporters (13). GT1 and GT4 have been associated with a higher degree of IR in the presence or absence of type 2 diabetes (T2D) (14). Additionally, HCV may promote gluconeogenesis by stimulating the expression of glucose 6-phosphate (G6P) and phosphoenolpyruvate carboxykinase 2 , also augmenting IR $(3,7,15,16)$. IR serves a key role in the development of severe complications, including fibrosis and hepatic steatosis, cirrhosis, liver cancer and therapeutic failure to achieve sustained viral response (SVR) (17).

Certain therapies, including supplementation with branched-chain amino acids (BCAAs), can increase insulin sensitivity and decrease IR $(18,19)$. Under conditions of IR, BCAAs have been reported to activate phosphoinositide-3 kinase (PI3K), which increased insulin action (increased insulin sensitivity and/or decreased IR) and enabled cellular glucose entry and mTOR-mediated protein synthesis (20-22). In patients with chronic hepatitis $\mathrm{C}(\mathrm{CHC})$, the serum levels of BCAAs (leucine, valine and isoleucine) are relatively low compared with those of aromatic amino acids (AAA; tryptophan, phenylalanine and tyrosine) and methionine (23). A low BCAA/AAA ratio has been documented to reduce the biosynthesis and secretion of albumin in hepatocytes and has also been associated with the prognosis of patients with chronic liver disease $(24,25)$. Oral supplementation with BCAAs may lower blood glucose $(26,27)$ and mitigate $\mathrm{CHC}(28,29)$, and in the liver, BCAAs may suppress the expression of G6P and thus the final step of gluconeogenesis (30-32).

Health-related quality of life (HR-QoL) is considered a determinant of health status. Generally, the HR-QoL of patients with $\mathrm{CHC}$ deteriorates over the course of the infection $(33,34)$. Previous studies have suggested that BCAA supplementation improves weakness and fatigue compared with other commonly prescribed diets, as indicated by improved scores in 36-item Short Form Health Surveys (SF-36) (35,36). However, the association between BCAAs and the HR-QoL of patients with $\mathrm{CHC}$ is yet to be investigated. Therefore, the present study evaluated the effect of BCAA supplementation, taken once daily for 3 months, on IR and HR-QoL in patients with CHC.

\section{Materials and methods}

Study design and patients. An experimental, single-arm pilot study was conducted at the Hospital de Infectología, Centro Medico Nacional La Raza (Infectious Diseases Hospital, National Medical Center, La Raza, Mexico City, Mexico) between February 2015 and December 2015. The selected $\mathrm{CHC}$ patients (age $\geq 18$ years) were diagnosed by the presence of HCV antibodies and confirmed by serum viral load detection using reverse transcription polymerase chain reaction (RT-PCR) and genotyping. Patients included were nonresponders to peginterferon $\alpha(\mathrm{PEG}-\mathrm{INF} \alpha)$ and ribavirin $(\mathrm{RBV})$ and had completed antiviral treatment at least 3 months prior to the start of the study. Patients with T2D or co-infected with hepatitis B virus or human immunodeficiency virus were excluded. All patients participated voluntarily and signed an informed consent letter. The protocol was conducted in accordance with the Declaration of Helsinki, and approved by the Local Committee of Health Research of the Mexican Social Security Institute (Mexico City, Mexico) under registration number R-2015-3502-71. Patients were orally administered 30 g/day BCAA (HEPA-AYDSA ${ }^{\circledR}$; Aminas y Derivados S.A. de C.V.; Mexico City, Mexico) on an empty stomach after a minimum 10-h overnight fast for 3 months. To ensure that patients adhered to the regiment, visits were scheduled at 15-day intervals. At these visits, patients were given the supplement and had their previous supplement package reviewed.

Measurements. Peripheral blood samples were obtained by venipuncture at 0 (baseline) and 3 months after the start of supplementation following a minimum 10 -h overnight fast. Serum was obtained by centrifugation at 2,000 x g for $15 \mathrm{~min}$ at room temperature. The isolated fraction was used to determine glucose, insulin, albumin, triglyceride, cholesterol, alanine aminotransferase (ALT) and aspartate aminotransferase (AST) levels. Serum glucose concentration was measured by the glucose hexokinase enzymatic UV test method using an Architect c16000 clinical chemistry analyzer (Abbott Pharmaceutical, Co., Ltd., Lake Bluff, IL, USA). Insulin level was assessed by radioimmunoassay (RIA) using a commercial human insulin-specific RIA kit (cat. no.: HI-14K; EMD Millipore, Billerica, MA, USA), according to the manufacturer's protocol. Albumin, triglyceride, cholesterol, ALT and AST levels were quantified using the automated Architect c16000 system. Specifically, albumin concentration was measured by bromocresol green reaction whereas triglyceride concentration was measured from enzyme products produced by lipoprotein lipase; ALT and AST levels were determined spectrophotometrically by NADH decrease, and cholesterol level by quinonimine formation. Hemoglobin concentration was evaluated using a Cell-Dyn Ruby Hematology Analyzer system (Pharmaceutical, Co., Ltd.), according to the manufacturer's protocol. Leukocyte count was determined by flow cytometry using a Beckman Coulter counter (DxH 800; Beckman Coulter, Inc., Brea, CA, USA), according to the manufacturer's protocol. IR and pancreatic $\beta$-cell secretory capacity were assessed using the Homeostasis Model Assessment (HOMA) (37). HOMA-IR and $-\beta$-cell function $(-\beta \%)$ were calculated according to the following formulas: HOMA-IR = fasting glucose $(\mathrm{mmol} / \mathrm{l}) \mathrm{x}$ fasting insulin $(\mu \mathrm{UI} / \mathrm{l}) / 22.5$, with the cutoff value for IR set to 3 (38); HOMA- $\beta \%=[20 \mathrm{x}$ fasting insulin $(\mu \mathrm{UI} / 1)] /[$ fasting glucose $(\mathrm{mmol} / \mathrm{l})-3.5]$, with the reference range for normal $\beta$-cell function as $67-68 \%$ (39). HCV viral load was determined by RT-PCR using a Procleix Tigris System (Grifols, California, USA), according to the manufacturer's instructions. HR-QoL was assessed at baseline and after 3 months of BCAA treatment using the SF-36 questionnaire $(39,40)$. Body-mass index (BMI) was calculated as weight divided by height squared $\left(\mathrm{kg} / \mathrm{m}^{2}\right)$. Patients with a BMI $\leq 25 \mathrm{~kg} / \mathrm{m}^{2}$ were considered normal weight whereas those with BMI between $25-30 \mathrm{~kg} / \mathrm{m}^{2}$ were considered overweight (41). Baseline fibrosis (METAVIR) score was measured by magnetic resonance imaging $(42,43)$. 
Table I. Effect of branched-chain amino acid supplementation on HCV viral load, glycemic profile, HOMA-IR, HOMA- $\beta \%$ and albumin, cholesterol and triglycerides levels after 3 months of treatment.

\begin{tabular}{lccc}
\hline Category & Basal & End of treatment & P-value $^{\mathrm{a}}$ \\
\hline Body-mass index $\left(\mathrm{kg} / \mathrm{m}^{2}\right)$ & $24.1(23.5-26.9)$ & $25.5(24.1-29.0)$ & $0.002^{\mathrm{b}}$ \\
Aspartate aminotransferase $(\mathrm{U} / \mathrm{l})$ & $85.5(55.3-112.5)$ & $80.5(47.5-103.3)$ & $0.028^{\mathrm{b}}$ \\
Alanine aminotransferase $(\mathrm{U} / \mathrm{l})$ & $83.5(61.8-96.0)$ & $66.0(45.5-94.3)$ & $0.008^{\mathrm{b}}$ \\
Albumin $(\mathrm{g} / \mathrm{dl})$ & $3.9(3.6-4.1)$ & $4.2(3.9-4.5)$ & $0.008^{\mathrm{b}}$ \\
Cholesterol $(\mathrm{mg} / \mathrm{dl})$ & $136(110-163)$ & $135(115-157)$ & 0.654 \\
Triglycerides $(\mathrm{mg} / \mathrm{dl})$ & $98(68-156)$ & $83(74-117)$ & 0.080 \\
RNA HCV $(\log 10)$ & $5.9(5.0-6.2)$ & $5.2(4.4-6.2)$ & 0.084 \\
Hemoglobin $(\mathrm{g} / \mathrm{dl})$ & $14.9(14.3-15.4)$ & $15.3(14.3-15.7)$ & $0.027^{\mathrm{b}}$ \\
Leukocytes $\left(10^{3} / \mu \mathrm{l}\right)$ & $4.50(3.56-5.76)$ & $14(9-22)$ & $0.003^{\mathrm{b}}$ \\
Insulin $(\mu \mathrm{U} / \mathrm{l})$ & $16(11-31)$ & $6.7(6.1-7.4)$ & $0.014^{\mathrm{b}}$ \\
Glucose $(\mathrm{nmol} / \mathrm{l})$ & $6.9(6.4-7.4)$ & $3.2(1.9-5.0)$ & 0.732 \\
HOMA-IR & $3.5(2.6-7.9)$ & $136(119-253)$ & $0.006^{\mathrm{b}}$ \\
HOMA- $\beta(\%)$ & $215(145-439)$ & 0.073
\end{tabular}

Values are presented as the median and interquartile range. ${ }^{a}$ Wilcoxon signed-rank test; ${ }^{b}$ significant to $\mathrm{P}<0.05$ (two-tailed). $\mathrm{HCV}$, hepatitis $\mathrm{C}$ virus; HOMA-IR, Homeostasis Model Assessment of IR; HOMA- $\beta$, Homeostasis Model Assessment of $\beta$-cell function.

Table II. Effect of branched-chain amino acid supplementation on health-related quality of life based on the 36-item Short Form Health Survey.

\begin{tabular}{llcr}
\hline Category & \multicolumn{1}{c}{ Basal } & End of 3-month treatment & P-value $^{\mathrm{a}}$ \\
\hline General health & $30.0(21.0-36.0)$ & $32.0(25.0-40.0)$ & 0.178 \\
Physical function & $82.5(51.2-95.0)$ & $80.0(55.0-95.0)$ & 0.938 \\
Physical health problems & $35.0(0.0-40.0)$ & $40.0(40.0-40.0)$ & $0.017^{\mathrm{b}}$ \\
Emotional problems & $30.0(2.5-30.0)$ & $30.0(30.0-30.0)$ & $0.026^{\mathrm{b}}$ \\
Emotional function & $29.0(24.5-30.0)$ & $30.0(27.0-30.8)$ & 0.433 \\
Energy fatigue & $20.0(18.0-20.0)$ & $19.2(17.1-21.5)$ & 0.948 \\
Social function & $13.5(9.1-18.0)$ & $17.5(15.6-20.0)$ & $0.008^{\mathrm{b}}$ \\
Pain & $18.0(13.5-20.0)$ & $17.0(13.5-20.0)$ & 0.797 \\
\hline
\end{tabular}

Values are presented as the median and interquartile range. ${ }^{a}$ Wilcoxon signed-rank test; ${ }^{\text {b }}$ significant to $\mathrm{P}<0.05$ (two-tailed).

Statistical analysis. The Shapiro-Wilk test was used to evaluate normality. To analyze the descriptive variables, medians and interquartile ranges (IQRs) were used. The quantitative variables, used to evaluate changes in the concentrations of serum factors throughout the treatment period, were analyzed by the Wilcoxon signed-rank test. Changes in HR-QoL determined from SF-36 questionnaires were also analyzed by the Wilcoxon signed-rank test. The statistical analyses were performed using SPSS software version 20 (IBM Corp., Armonk, NY, USA) and $\mathrm{P}<0.05$ (two-tailed) was considered to indicate significance.

\section{Results}

Basal characteristics of the study population. A total of 20 patients (median age $=53$; IQR, 45-63), who exhibited no response to PEG-INF $\alpha / \mathrm{RBV}$, were selected for the study.
Among these, 5 patients also failed to elicit a response to alternative treatments ( 3 to boceprevir and 2 to telaprevir). All patients underwent $\geq 3$ months of antiviral treatment cessation and exhibited no notable side effects from treatment withdrawal. During the 3-month BCAA treatment period, 2 patients developed a throat infection and were prescribed antibiotics; however, removing these patients from the analysis did not change the results. According to the adherence assessment, all subjects consumed $\geq 95 \%$ of the supplement. Of the 20 patients that were included in the study, 10 were male. A total of 9 patients presented with the GT1a genotype, 7 with the GT1b genotype and 4 with the GT2a genotype. The baseline fibrosis (METAVIR) score was F3 in 8 patients (40\%) and F4 in 12 patients $(60 \%)$.

Effect of 3-month BCAA treatment on biochemical parameters. At baseline, $60 \%$ of patients were normal weight (BMI 
$<25 \mathrm{~kg} / \mathrm{m}^{2}$ ); however, following the 3-month treatment period, this decreased to $45 \%$. Notably, there was a significant increase in median BMI by the end of the treatment period compared with baseline ( $\mathrm{P}=0.002$; Table I). There were no significant changes in median fasting blood glucose and cholesterol levels after the 3-month treatment period. Additionally, although the majority of the patients exhibited decreased triglyceride levels and decreased viral load (68 and 60\%, respectively), the median values of these parameters were not significantly altered after the $\mathrm{BCAA}$ regimen $(\mathrm{P}=0.080$ and $\mathrm{P}=0.084$, respectively). Conversely, the BCAA treatment caused significant decreases in the serum levels of the AST and ALT $(\mathrm{P}=0.028$ and $\mathrm{P}=0.008$, respectively), whereas the concentrations of hemoglobin and leukocytes were increased $(\mathrm{P}=0.027$ and $\mathrm{P}=0.003$, respectively). BCAA treatment also significantly increased albumin $(\mathrm{P}=0.008)$ and insulin levels $(\mathrm{P}=0.014)$ (Table I).

The majority of the subjects $(85 \%)$ exhibited some level of improvement in HOMA-IR score with BCAA treatment, and at 3 months post-treatment, the overall decrease in the median HOMA-IR score was determined to be significant $(\mathrm{P}=0.006$; Table I). Furthermore, at the start of the study, $70 \%$ of the patients were positive for IR; however, following BCAA treatment, this was decreased to $50 \%$. The median basal HOMA- $\beta \%$ also decreased, though this was not significant ( $\mathrm{P}=0.073$; Table I). Interestingly, the reversal of IR positivity with improved HOMA- $\beta \%$ score in $10(50 \%)$ patients suggests compensatory secretion and indicates that $\beta$-secretion capacity was conserved. In the remaining 10 patients, HOMA-IR did not change with improved $\beta$-cell function, indicating normoglycemia with increased insulin secretion.

Effect of 3-month BCAA treatment on HR-QoL parameters. The HR-QoL of patients, assessed using the SF-36 questionnaire, was significantly improved in three of the eight aspects evaluated: Role limitations due to physical health problems $(\mathrm{P}=0.017)$, role limitations due to emotional problems $(\mathrm{P}=0.026)$ and social function $(\mathrm{P}=0.008$, Table II $)$.

\section{Discussion}

Previous studies have proposed the use of BCAA supplementation for the treatment of hepatic encephalopathy $(36,44)$, and others have noted improved nutritional balance and a decreased frequency of cirrhosis-related complications with BCAA supplementation (45-47). In addition to the nutritional role of BCAAs, studies have also evaluated patient QoL based on SF-36 tests $(46,47)$. However, the effect of BCAA supplementation on IR and its association with viral load is less understood $(29,30)$. In the present study, it was demonstrated that treatment with BCAA supplementation decreased IR and improved HR-QoL.

HR-QoL is an important parameter for assessing overall QoL. In the current study, the BCAA treatment significantly improved the HR-QoL of patients in three of the eight aspects evaluated: Role limitations due to physical health problems, role limitations due to emotional problems and social function. Limitations due to physical health are linked to an individual's ability to perform activities, whereas role limitations due to emotional problems and social function influence one's ability to integrate into his or her environment. Overall, seven of the aspects evaluated were improved to a degree.

In $80 \%$ of the patients, previous treatments had exerted significant adverse effects during the time the antiviral was administered. In the current study, prior to BCAA treatment, the patients had an average weight loss of $\sim 10 \mathrm{~kg}$, all exhibited thrombocytopenia, and some exhibited severe irritability, insomnia, fatigue, hair loss and joint pain. However, these side effects were undetectable or unacknowledged by the patient at the time the BCAA was administered. Patients noted improvement in sleep balance and increased physical energy within the first month of the supplementation with BCAA (4 months after stopping antiviral therapy), which was confirmed by the SF-36 questionnaire at 3 months post-BCAA treatment. This may have been due to the BCAA treatment, as BCAA specifically targets mTOR by activating protein synthesis, reflected by the significant increases in serum albumin. This suggests that the BCAA supplementation improved the nutritional status of the patient and with it their perception of well-being, which may be considered as an improvement in HR-QoL.

The current study also identified that BCAA supplementation improved hepatic protein synthesis and attenuated IR. All patients exhibited normal serum glucose throughout the study, which was expected due to the exclusion of patients with T2D. Conversely, a range of serum insulin levels were detected, potentially due to individual factors, including $\mathrm{CHC}$ evolution and age. For the present cohort, the gender of the patient or HCV genotype was not associated with insulin levels or IR (data not shown). Patients who initially presented with insulin levels above the normal range exhibited significantly decreased insulin production and IR. Changes in IR were markedly more discrete in patients with normal baseline insulin levels; however, these patients demonstrated no change in IR and increased $\beta$-cell function following treatment, indicating enhanced insulin secretion and thus IR.

Elevated albumin was detected in all patients, and $>70 \%$ of the patients exhibited marginally decreased triglyceride and cholesterol levels. Albumin production was increased in an indirect manner, indicating that the BCAAs activated hepatic protein synthesis, probably through mTOR $(25,48)$. At present, the role of BCAAs and their implications in the development of IR remain controversial. Indeed, in obese or overweight individuals, BCAAs have been reported to induce IR (49).

In the present study, BCAA supplementation was administered for 3 months. Conversely, in previous studies, BCAA supplementation has been provided for 1-2 years $(31,32)$. Nevertheless, the current study observed a significant decrease in IR, probably due to the relatively high administered dose (30 g/day) and, unlike in other studies, the administration of BCAAs on an empty stomach, which may have increased absorption.

According to the current results, for patients with $\mathrm{CHC}$, BCAA supplementation improved IR and stimulated protein synthesis. Additionally, the HOMA-IR and HOMA- $\beta \%$ relationship was decreased in 10 patients, thus suggesting conservation of the secretory capacity of the pancreas and indicating salvageability of its function.

In the 10 patients with improved $\beta$-cell function only, normoglycemia coexisted with increased insulin secretion, 
suggestive of IR. BCAA supplementation is a potential method of preventing or delaying the development of T2D in these patients. Previous results have indicated an association between IR and SVR (18); however, in the current study, this association was not evaluated as the study population was not under antiviral regimen, although viral loads did decrease.

The present study had some limitations. Firstly, the patients were not under the supervision of a nutritionist, and thus food consumption probably varied in terms of content and quantity between individuals. Secondly, the physical routines of patients was not considered. Exercise has been reported to reduce IR (50); however, physical activity likely varied between the current patients. Controlling these factors may further validate the improvement in IR observed. Thirdly, as the study was a pilot, the sample size was small and no control group was recruited. Therefore, the results should be verified in a larger sample size and with an increased duration and/or frequency of supplementation. Regarding a non-BCAA-treated group, similar results regarding insulin and IR have been identified in treated groups (51), and as the current study focus was to characterize the effect of BCAA supplementation on IR and HR-QoL, there may have been little benefit to including a non-BCAA treatment group. Finally, the relatively short treatment duration of 3 months the treatment may have limited results; however, this is a typical follow-up time for patients under normal clinical settings, and thus was considered an optimal time for determining whether continuation of BCAA supplementation would be an appropriate course. Nevertheless, analyses of the long-term effects of BCAA supplement on HR-QoL are currently underway by our group.

In conclusion, a high percentage of patients with $\mathrm{CHC}$ exhibit IR. BCAA supplementation decreased IR, and thus may be an effective therapeutic strategy in the treatment of hepatitis $\mathrm{C}$ infection. BCAA also supplementation improved HR-QoL, hepatic protein synthesis and lipid metabolism. In developing countries where public health institutions lack modern antiviral therapies for improving SVR, alternative strategies such as BCAA supplementation should be implemented.

\section{Acknowledgements}

The authors are thankful to the participants of the study, to Mario Uriarte López (AYDSA Aminas y Derivados S.A. de C.V) for donating the BCAA supplement and to Dr Leonardo M. Porchia (Laboratorio de Investigación en Fisiopatología de Enfermedades Crónicas, Centro de Investigación Biomédica de Oriente), who contributed to the preparation of the manuscript.

\section{References}

1. El Serag HB: Epidemiology of viral hepatitis and hepatocellular carcinoma. Gastroenterology 142: 12641273 e1261, 2012. https://doi.org/10.1053/j.gastro.2011.12.061.

2. Lozano-Sepulveda SA, Bryan-Marrugo OL, Cordova-Fletes C, Gutierrez-Ruiz MC and Rivas-Estilla AM: Oxidative stress modulation in hepatitis $\mathrm{C}$ virus infected cells. World J Hepatol 7: 2880-2889, 2015 .

3. Romero-Gómez M: Insulin resistance and hepatitis C. World J Gastroenterol 12: 7075-7080, 2006.

4. García-Montalvo BM and Macossay-Castillo M: Preliminary data for genotype distribution and epidemiological aspects of hepatitis $\mathrm{C}$ virus infection in blood donors from Yucatan, Mexico. Transfus Med 17: 488-490, 2007.
5. Koike K, Tsutsumi T, Yotsuyanagi $\mathrm{H}$ and Moriya K: Lipid metabolism and liver disease in hepatitis $\mathrm{C}$ viral infection. Oncology 78 (Suppl 1): 24-30, 2010.

6. Chang ML: Metabolic alterations and hepatitis C: From bench to bedside. World J Gastroenterol 22: 1461-1476, 2016.

7. Sheikh MY, Choi J, Qadri I, Friedman JE and Sanyal AJ: Hepatitis $\mathrm{C}$ virus infection: Molecular pathways to metabolic syndrome. Hepatology 47: 2127-2133, 2008.

8. Milner KL, Jenkins AB, Trenell M, Tid-Ang J, Samocha-Bonet D, Weltman M, Xu A, George J and Chisholm DJ: Eradicating hepatitis $\mathrm{C}$ virus ameliorates insulin resistance without change in adipose depots. J Viral Hepat 21: 325-332, 2014.

9. Bose SK and Ray R: Hepatitis C virus infection and insulin resistance. World J Diabetes 5: 52-58, 2014.

10. Parvaiz F, Manzoor S, Tariq H, Javed F, Fatima K and Qadri I: Hepatitis $\mathrm{C}$ virus infection: Molecular pathways to insulin resistance. Virol J 8: 474, 2011.

11. Kim KA, Lin W, Tai AW, Shao RX, Weinberg E, De Sa Borges CB, Bhan AK, Zheng H, Kamegaya Y and Chung RT: Hepatic SOCS3 expression is strongly associated with nonresponse to therapy and race in HCV and HCV/HIV infection. J Hepatol 50: 705-711, 2009.

12. Banerjee A, Meyer K, Mazumdar B, Ray RB and Ray R: Hepatitis $C$ virus differentially modulates activation of forkhead transcription factors and insulin-induced metabolic gene expression. J Virol 84: 5936-5946, 2010.

13. Deltenre P, Louvet A, Lemoine M, Mourad A, Fartoux L, Moreno C, Henrion J, Mathurin P and Serfaty L: Impact of insulin resistance on sustained response in $\mathrm{HCV}$ patients treated with pegylated interferon and ribavirin: A meta-analysis. J Hepatol 55: 1187-1194, 2011.

14. Mason AL, Lau JY, Hoang N, Qian K, Alexander GJ, Xu L, Guo L, Jacob S, Regenstein FG, Zimmerman R, et al: Association of diabetes mellitus and chronic hepatitis $\mathrm{C}$ virus infection. Hepatology 29: 328-333, 1999.

15. Bose SK, Shrivastava S, Meyer K, Ray RB and Ray R: Hepatitis C virus activates the $\mathrm{mTOR} / \mathrm{S} 6 \mathrm{~K} 1$ signaling pathway in inhibiting IRS-1 function for insulin resistance. J Virol 86: 6315-6322, 2012.

16. Deng L, Shoji I, Ogawa W, Kaneda S, Soga T, Jiang DP, Ide YH and Hotta $\mathrm{H}$ : Hepatitis $\mathrm{C}$ virus infection promotes hepatic gluconeogenesis through an NS5A-mediated, FoxO1-dependent pathway. J Virol 85: 8556-8568, 2011.

17. Knobler $\mathrm{H}$ and Malnick S: Hepatitis $\mathrm{C}$ and insulin action: An intimate relationship. World J Hepatol 8: 131-138, 2016.

18. Romero-Gómez M, Del Mar Viloria M, Andrade RJ, Salmerón J, Diago M, Fernández-Rodríguez CM, Corpas R, Cruz M, Grande L, Vázquez L, et al: Insulin resistance impairs sustained response rate to peginterferon plus ribavirin in chronic hepatitis C patients. Gastroenterology 128: 636-641, 2005.

19. De Bandt JP and Cynober L: Therapeutic use of branched-chain amino acids in burn, trauma, and sepsis. J Nutr 136: 308S-313S, 2006.

20. Wullschleger $\mathrm{S}$, Loewith $\mathrm{R}$ and Hall $\mathrm{MN}$ : TOR signaling in growth and metabolism. Cell 124: 471-484, 2006.

21. Averous J and Proud CG: When translation meets transformation: The mTOR story. Oncogene 25: 6423-6435, 2006.

22. Nobukuni T, Kozma SC and Thomas G: hvps34, an ancient player, enters a growing game: mTOR Complex1/S6K1 signaling. Curr Opin Cell Biol 19: 135-141, 2007.

23. Abad-Lacruz A,Cabré E, González-Huix F, Fernández-Bañares F, Esteve M, Planas R, Llovet JM, Quer JC and Gassull MA: Routine tests of renal function, alcoholism, and nutrition improve the prognostic accuracy of Child-Pugh score in nonbleeding advanced cirrhotics. Am J Gastroenterol 88: 382-387, 1993.

24. Blonde-Cynober F, Aussel C and Cynober L: Abnormalities in branched-chain amino acid metabolism in cirrhosis: Influence of hormonal and nutritional factors and directions for future research. Clin Nutr 18: 5-13, 1999.

25. Okuno M, Moriwaki H, Kato M, Muto Y and Kojima S: Changes in the ratio of branched-chain to aromatic amino acids affect the secretion of albumin in cultured rat hepatocytes. Biochem Biophys Res Commun 214: 1045-1050, 1995.

26. She P, Reid TM, Bronson SK, Vary TC, Hajnal A, Lynch CJ and Hutson SM: Disruption of BCATm in mice leads to increased energy expenditure associated with the activation of a futile protein turnover cycle. Cell Metab 6: 181-194, 2007.

27. Korenaga K, Korenaga M, Uchida K, Yamasaki T and Sakaida I: Effects of a late evening snack combined with alpha-glucosidase inhibitor on liver cirrhosis. Hepatol Res 38: 1087-1097, 2008. 
28. Sakaida I, Tsuchiya M, Okamoto M and Okita K: Late evening snack and the change of blood glucose level in patients with liver cirrhosis. Hepatol Res 30S: 67-72, 2004.

29. Kawaguchi T, Nagao Y, Matsuoka H, Ide T and Sata M: Branched-chain amino acid-enriched supplementation improves insulin resistance in patients with chronic liver disease. Int J Mol Med 22: 105-112, 2008.

30. Kawaguchi T, Taniguchi E, Itou M, Sumie S, Oriishi T, Matsuoka H, Nagao Y and Sata M: Branched-chain amino acids improve insulin resistance in patients with hepatitis $C$ virus-related liver disease: Report of two cases. Liver Int 27: 1287-1292, 2007.

31. Syed GH, Amako Y and Siddiqui A: Hepatitis C virus hijacks host lipid metabolism. Trends Endocrinol Metab 21: 33-40, 2010.

32. Amako Y, Munakata T, Kohara M, Siddiqui A, Peers C and Harris $\mathrm{M}$ : Hepatitis $\mathrm{C}$ virus attenuates mitochondrial lipid $\beta$-oxidation by downregulating mitochondrial trifunctional-protein expression. J Virol 89: 4092-4101, 2015.

33. Ramcharran D, Wahed AS, Conjeevaram HS, Evans RW, Wang T, Belle SH and Yee LJ: Serum lipids and their associations with viral levels and liver disease severity in a treatment-naïve chronic hepatitis C type 1-infected cohort. J Viral Hepat 18: e144-e152, 2011.

34. Gross CR, Malinchoc M, Kim WR, Evans RW, Wiesner RH, Petz JL, Crippin JS, Klintmalm GB, Levy MF, Ricci P, et al: Quality of life before and after liver transplantation for cholestatic liver disease. Hepatology 29: 356-364, 1999.

35. Kawamura N, Nakajima $\mathrm{H}$ and Takashi SI: Administration of granulated BCAA and quality of life. Hepatol Res 30S: 42-45, 2004.

36. Kawaguchi T, Taniguchi E and Sata M: Effects of oral branchedchain amino acids on hepatic encephalopathy and outcome in patients with liver cirrhosis. Nutr Clin Pract 28: 580-588, 2013.

37. Levy JC, Matthews DR and Hermans MP: Correct homeostasis model assessment (HOMA) evaluation uses the computer program. Diabetes Care 21: 2191-2192, 1998.

38. Hernández Yero JA, Tuero Iglesias Á and Vargas González D: Utilidad del índice HOMA IR con una sola determinación de insulinemia para diagnosticar resistencia insulínica. Rev Cuba Endocrinol 22: 69-77, 2011.

39. Buccini GS and Wolfthal DL: Valores de corte para índices de insulinorresistencia, insulinosensibilidad e insulinosecreción derivados de la fórmula HOMA y del programa HOMA2: Interpretación de los datos. Revista argentina de endocrinología y metabolismo 45: 03 21, 2008.

40. Vilagut G, Ferrer M, Rajmil L, Rebollo P, PermanyerMiralda G, Quintana JM, Santed R, Valderas JM, Ribera A, Domingo-Salvany A, et al: El Cuestionario de Salud SF-36 español: Una década de experiencia y nuevos desarrollos. Gac Sanit 19: 135-150, 2005.
41. Garrouste-Orgeas M, Troché G, Azoulay E, Caubel A, de Lassence A, Cheval C, Montesino L, Thuong M, Vincent F, Cohen Y, et al: Body mass index. An additional prognostic factor in ICU patients. Intensive Care Med 30: 437-443, 2004.

42. Rouvière O, Yin M, Dresner MA, Rossman PJ, Burgart LJ, Fidler JL and Ehman RL: MR elastography of the liver: Preliminary results. Radiology 240: 440-448, 2006.

43. Bota S, Sirli R, Sporea I, Focsa M, Popescu A, Danila M, Strain M, Sendroiu M, Deleanu A and Dan I: A new scoring system for prediction of fibrosis in chronic hepatitis C. Hepat Mon 11: 548-555, 2011.

44. Gluud C, Conn HO and Eriksson LS: Branched-chain amino acids for hepatic encephalopathy? Hepatology 13: 812-813, 1991.

45. Charlton M: Branched-chain amino acid enriched supplements as therapy for liver disease. J Nutr 136: 295S-298S, 2006.

46. Chen L, Chen Y, Wang X, Li H, Zhang H, Gong J, Shen S, Yin W and $\mathrm{Hu} \mathrm{H}$ : Efficacy and safety of oral branched-chain amino acid supplementation in patients undergoing interventions for hepatocellular carcinoma: A meta-analysis. Nutr J 14: 67, 2015.

47. Muto Y, Sato S, Watanabe A, Moriwaki H, Suzuki K, Kato A, Kato M, Nakamura T, Higuchi K, Nishiguchi S, et al; Long-Term Survival Study Group: Effects of oral branched-chain amino acid granules on event-free survival in patients with liver cirrhosis. Clin Gastroenterol Hepatol 3: 705-713, 2005

48. Higuchi N, Kato M, Miyazaki M, Tanaka M, Kohjima M, Ito T, Nakamuta M,Enjoji M, Kotoh K and Takayanagi R: Potential role of branched-chain amino acids in glucose metabolism through the accelerated induction of the glucose-sensing apparatus in the liver. J Cell Biochem 112: 30-38, 2011

49. Adeva MM, Calviño J, Souto G and Donapetry C: Insulin resistance and the metabolism of branched-chain amino acids in humans. Amino Acids 43: 171-181, 2012.

50. Knowler WC, Narayan KM, Hanson RL, Nelson RG, Bennett PH, Tuomilehto J, Scherstén B and Pettitt DJ: Preventing non-insulindependent diabetes. Diabetes 44: 483-488, 1995.

51. Takeshita Y, Takamura T, Kita Y, Ando H, Ueda T, Kato K, Misu H, Sunagozaka H, Sakai Y, Yamashita T, et al: Beneficial effect of branched-chain amino acid supplementation on glycemic control in chronic hepatitis $\mathrm{C}$ patients with insulin resistance: Implications for type 2 diabetes. Metabolism 61: 1388-1394, 2012. 